\title{
Awareness and Knowledge about Atal Pension Yojana among individuals in Kerala
}

\author{
Anjana Devi.S \\ Research scholar, SD College Alappuzha, University of Kerala \\ E-mail:anjanadevi2369@gmail.com \\ Ph.no:7025911460 \\ DOI: 10.29322/IJSRP.11.01.2021.p10959 \\ http://dx.doi.org/10.29322/IJSRP.11.01.2021.p10959
}

\begin{abstract}
Atal Pension Yojana is a pension scheme provided by Government of India, primarily targeted at the unorganized sector. A large number of persons employed in India worked in unorganized sector. Employees of enterprises belonging to the unorganized sector have lower job security and poorer chances for growth, and no leave or paid holidays, they have lower protection against employers indulging in unfair or illegal practices. Thus a pension scheme is essential for them and APY scheme provide such benefit for workers in unorganized sector. This paper is an attempt to find out awareness level of individuals about Atal Pension Yojana.
\end{abstract}

Keywords: Unorganised sector, PFRDA, APY

\section{INTRODUCTION}

Atal Pension Yojana (Previously known as Swavalamban yojana) is a Government backed Pension scheme provided in India at unorganized sector. It was announced in 2015 Budget speech by Finance minister Arun Jaitley. It was launched by Prime minister Narendra Modi on $9^{\text {th }}$ May in Kolkatta. APY scheme was applicable to all citizens in the unorganized sector who joined the NPS(National Pension System)administered by the PFRDA(Pension Fund Regulatory and Development Authority) Act 2013.A fixed monthly pension amount starting from Rs.1000,Rs.2000,Rs.3000,Rs.4000 and up to Rs.5000 can be received by subscribers, every month after their retirement at the age of 60, until the death of the subscriber. After the death of the account holder, the spouse will be entitled to get the exact same pension amount as the subscriber, until the death of spouse. This fixed pension amount varies yet again with the contribution the subscriber has made previously. To get the maximum benefit from the Atal Pension Yojana scheme, individuals should join this plan at the age of 18 and contribute, till they turn 40.

\section{OBJECTIVES}

1. To study about awareness of individuals in relation to APY scheme.

2. To find out reason for non-awareness, if any.

3. To find out benefits and limitations, if any of APY scheme.

4. 3. To study about operational framework of APY scheme.

\section{STATEMENT OF THE PROBLEM}

Central Government introduces various insurance as well as pension schemes to promote savings in our country. Atal Pension

Yojana was launched in May 2015.This scheme mainly concentrates on unorganized sector. APY scheme is beneficial to all This publication is licensed under Creative Commons Attribution CC BY. 
citizen of India, aged between 18 years and 40 years who has his/her bank account.APY is the largest Pension scheme announced by Arun Jaitley. But comparing to other states, number of subscribers in Kerala is comparatively low. The top ten states in APY mobilization are Uttar Pradesh, Bihar, Tamilnadu, Maharashtra, Karnataka, Andhra Pradesh, West Bengal, Madhya Pradesh, Rajasthan and Gujarat.

\section{SIGNIFICANCE OF THE STUDY}

Atal Pension Yojana (APY) is a Pension Scheme for citizens of India, is focused on unorganized sector workers includes weavers, handloom workers, fishermen, leather workers etc. Under this scheme, individuals between the age group of 18-40 are allowed to get pension after they attain the age of 60 by small contributions to pension fund. The amount of pension depends on their contribution towards pension fund. Interested individuals can subscribe this scheme from banks or post office. Number of customers for APY scheme is increases from year to year. But strength of APY scheme is comparatively low in Kerala. Thus the present study concentrated on study of awareness and knowledge on APY scheme expected to spread knowledge about this scheme and increase subscribers in Kerala.

\section{SCOPE OF THE STUDY}

Present study on awareness and knowledge of individuals about APY scheme is concentrated on Thiruvananthapuram District. APY scheme is one of the important pension scheme directly offered by Central Government to unorganized sector workers. Now this scheme is very popular in India and number of subscribers increased from year to year.But contribution from Kerala is comparatively low. Thus it is very essential to find out reasons for non subscription among individuals and make solutions for it.

\section{RESEARCH METHODOLOGY}

\section{$>$ Research Design.}

\section{Sources of data}

* Primary data

The primary data is collected using sampling method and survey using questionnaire.

* Secondary data

Secondary data includes information from newspapers, internet, and Reference books.

\section{$\underline{\text { Sample Design }}$}

In this study, I have used Convenience sampling method (Non-probability technique) to select samples from population.

Sample size $\quad: 120$ samples

Area of Research : : Urban and Rural areas in Thiruvananthapuram District.

\section{Data collection Method}

I have used 'survey method' to collect data. I have used' structured questionnaire' for gathering required data through contacting respondents personally. 


\section{Data Analysis \& Interpretation}

Data analysis is based on the data collected by way of questionnaire. The collected data are tabulated and interpretations are drawn.

\section{REVIEW OF LITERATURE}

Sudindra.V.R(2016) concluded that APY scheme is introduced to protect the unorganized sector workers will not serve the purpose of income security and retirement benefit. To cater the need of unorganized sector workforce government has to contribute more amount in the scheme.

Debashis Basu(2015) find out that the interest rate on APY during the accumulation stage is 7.94 per cent a month. That is below the current bank deposit rate. At the withdrawal stage,the interest rate is insultingly low- just 7.06 percent. Another problem is that the strong penalty for default in contribution; if you fail to contribute for six months, your account will be frozen; after 12 months, your account will be deactivated and after 24 months, the account will be closed. The basic feature of informal workers is that they do not have fixed income and so cannot pay a periodic and fixed contribution to a pension fund.

Vishnu Prasad and Anand Sahasranaman (2015) point out the two limitations of Atal Pension Yojana which includes lack of inflation indexation and conservative investment mix. Because of inflation the corpus may erode overtime hence to meet the goal of proposed NPS and $85 \%$ of fund will be invested in bonds which will effect the retirement corpus.

J.Sandeep \& namratha Sharma (2015) suggested that the expected rate of interest reduce in future as the economy grows and the contributors will remain getting $8 \%$ interest by enrolling themselves into scheme.

Vidyashree.D.V\&Prahlad Rathod (2015) concluded that the subscribers for PMJJBY,PMSBY and APY schemes are at increasing pase, however if implemented still more properly and the benefit is passed on to the real subscriber it will go a long way in establishing a social security system to the large section of society which has remain uncovered.

\section{AN OVERVIEW OF ATAL PENSION YOJANA}

\section{Eligibility for APY}

1. An Indian citizen

2. Have a valid bank account

3. Are between 18 and 40 years of age.

\section{Operational Framework of APY}

It is Government of India Scheme, which is administered by the Pension Fund Regulatory and Development Authority. The Institutional Architecture of NPS would be utilised to enrol subscribers under APY. The offer document of APY including the account opening form would be formulated by PFRDA.

\section{$\underline{\text { Penalties for default }}$}


Rs.1 per month for contribution upto Rs.100 per month.

Rs.2 per month for contribution upto Rs.101 to 500 per month.

Rs.5 per month for contribution between Rs.501 to 1000 per month.

Rs.10 per month for contribution beyond Rs.1001 per month.

\section{$\underline{\text { Advantages of APY }}$}

* Tax benefit: Tax benefit under Sec.80 CCD for the contributions made.

* Guaranteed Pension: Guaranteed minimum pension of Rs. 1000/- to Rs.5000/- per month.

* Pension to the spouse: In case of death of the subscriber, pension would be available to the spouse.

* Corpus to the Nominee: In case of death of the subscriber \& the spouse both, then the pension corpus would be returned to the nominee.

\section{$\underline{\text { Disadvantages }}$}

* Government contribution in Atal Pension Yojana is $50 \%$ of the premium or Rs 1000/- whichever is low but the govt's contribution comes to you only if you join this scheme on or before 31 Dec 2015. After that there will be no $50 \%$ contribution or Rs 1000/- contribution from Govt of India.

* Existing Subscriber of Swavalamban Scheme will automatically merge into Atal Pension Yojana, but if they want to stay in Swavalamban Scheme they need to inform.

* This Atal Pension Scheme is for an Indian whose Age is between 18 to 40. If a person whose age is above 40 or below 18 , he/she cannot get this facility of Guaranteed Pension.

* Considering a retirement corpus of Rs. 1.7 lakh and monthly pension of Rs. 1,000, this scheme is going to generate a return of $0.59 \%$ per month or $7.1 \%$ per annul for its subscribers. I think this return is also on a lower side.

* If a person who is running Atal Pension Yojana dies before the age of 60, the nominee will only get only the deposited amount.

* In Atal pension Yojana it is also not declared that the interest you will be getting after the age of 60 is either Taxable or Tax free.

* Every Year you have to Renew this scheme in your respective bank.

* The premium would be auto debited from your bank account. If you are not having sufficient fund in you account at that time, what will be the exact treatment is not clarified as of now.

* Atal Pension Yojana is only for those who are not enrolled in any pension Scheme like EPF, EPS .

\section{FINDINGS}

- Atal Pension Yojana provide merits like taxable benefits, guaranteed pension, pension to the spouse etc. but it has lot of disadvantages also.

○ Majority of respondents just heard about this scheme but they are not aware about its benefits, eligibility, contribution and procedure for starting APY pension account.

○ Government takes efforts to reach this scheme among local people through advertisements.

- Among respondents, the members of APY scheme is comparatively low. 


\section{SUGGESTIONS}

- Banks has to give more awareness about APY scheme among their customers

○ Government must conduct public campaigns at schools, colleges, public places etc. for making this scheme more transparent.

\section{CONCLUSION}

The Government of India is extremely concerned about the old age income security for employees depending on unorganized sector. Thus Modi Government introduced Atal Pension Yojana for satisfying those purpose. This scheme provide various benefits like Guaranteed pension, taxable benefit, pension to spouse and corpus to the nominee etc. but the problem is that majority of individuals are not aware about the operations of APY scheme. Thus they are not joined for this. So Government and banks jointly make effort to reach poor people and make the scheme more transparent among them

\section{REFERENCES}

1.Sudindra.V.R,Eeasibility Analysis of Atal Pension Yojana, International Journal of Advanced Research,2016,Volume 4,Issue 3 .

2.Dabashis Basu,Why Atal Pension Yojana may struggles,May 17,2015,Business standard.

3.Blog,By Vishnu Prasad \& Anand Sahasranaman ,IFMR Finance Foundation.

4. J.Sandeep \& namratha Sharma,A study on Atal Pension Yojana,International journal in Management and Social science ,volume 3,issue 7,July 2015.

5. Vidyashree.D.V\&Prahlad Rathod,FinanciL Inclusion- A Study on Modi'S PMJJBY,PMSBY and APY ,International Journal of Applied Research,June 2015.

6.http://financialservices.gov.in/APY.asp

7.http://npscra.nsdl.co.in

8.Economic times newspaper-30 ${ }^{\text {th }}$ May 2015 